\title{
Analysis of Industry University Research Institute Talents Training Mode in College Art Major
}

\author{
Xia Wang \\ School of Art, Xi'an University, 710065
}

Keywords: College art; Industry University research institute; Talents training mode; Research

\begin{abstract}
The curriculum educational objectives and settings in college art major are different from the teaching objectives and speak content in general specialty. College public art major emphasizes improving the manipulative ability, art aesthetic ability and comprehensive quality of college artistic talents by their emotional appeal. Different art majors have different analysis of talents training mode. The main analysis direction often seeks more intuition and publicity in artistic feature aspect and sociability of serving society. The establishment of industry university research institute joint development talents training mode is the final direction of many college art majors. It is because that all the artistic classes want to eventually achieve the purpose of socialization to create more value and make students truly achieve applying their learning. The paper aims at the problem of industry university research institute aspect in college public art major curriculum. And will give a brief review of some viewpoints about college art major talents training mode and researches on carrying out industry university research institute.
\end{abstract}

\section{Introduction}

Art major is a very important art branch in the process of university construction. Art is an important way to achieve aesthetic education. It is an effective educational mean for college students' comprehensive development in society. Under the background of the reform of college education, all the colleges have set up art courses extensively in order to conform to the trend of social situation reform. Whether it is public art major or specialized art major, they are all hoping to combine the artistic quality of college students and cultivate their artistic creation. Art major relatively has more detailed branch. They enable students' comprehensive quality and potential to draw more and more attention of all levels of education departments and colleges. Therefore, many art colleges adopt the way of industry university research institute and have got a lot of achievements. However, due to the development of industry university research institute is relatively advanced many colleges still have many shortcomings in applying this concept when training students.

\section{The Connotation of Industry University Research Institute Cooperation System Engineering}

Industry university research institute is connotation system engineering. Literally, it means system cooperation of production, learning, scientific research and practical application. In terms of the college, industry university research institute cooperative education is to take full advantage of college, enterprise and R \& D institution's different teaching environment and resources and their own advantages in talents training. It is the education form of organic combination of college education of classroom knowledge with production, scientific research and practice of directly obtaining practical experience and practical ability. Industry university research cooperation is only one letter short of industry university research institute cooperation, but latter further emphasizes apply. It stood out that industry university research cooperation must take enterprise as the main body and be market-oriented.

Industry university research institute is connotation system engineering. Literally, it means system cooperation of production, learning, scientific research and practical application. In terms of the college, industry university research institute cooperative education is to take full advantage of college, enterprise and R \& D institution's different teaching environment and resources and their 
own advantages in talents training. It is the education form of organic combination of college education of classroom knowledge with production, scientific research and practice of directly obtaining practical experience and practical ability. Industry university research cooperation is only one letter short of industry university research institute cooperation, but latter further emphasizes apply. It stood out that industry university research cooperation must take enterprise as the main body and be market-oriented. Institute mainly refers to apply and user. It is the starting point and the foothold of technological innovation. Users directly involved in industry university research cooperation can not only reduce the blindness of technological innovation, shorten the period from research and development to enter market of new products but also can effectively reduce the risk of technological innovation and cost. The nature of industry university research cooperation is to promote the combination of science and technology, education and economy. From what industry university research cooperation in China has experienced, we can see that further strengthening the close combination of industry university research institute is necessary in order to make industry university research cooperation get a result and make scientific achievements better transformed into real productivity. The successfully developed large water turbine generator and high-speed railway system in our country all adopted the approach of industry university research institute cooperation.

\section{The Talents Training Mode Content of College Art Major that Need to Adjust and Strengthen}

College art major need to adjust and strengthen the attention on talents training mode and method. The traditional college art major often adopt a training method of disjointing theory and practice. It is a kind of highbrow method. Many art colleges just teach students with pure theory at the earlier stage in order to make them have a better development on art and music. It is a more unpopular method for art major in learning.

Let students focus on improving art quality and ignore other aspects' ability training can improve their artistic accomplishment in a short time, but it is not conducive to the combination of art and practice for students in teaching and research, production and application. Therefore, in order to make art major better, make art theory and practice enjoy popular support and popularize art education in modern professional education process, it is necessary to informatively combine the existing talents training model and build distinctive and informative art design major applied talents training mode of industry university research institute cooperation in the process of running art school. Ultimately, it is aimed at contributing to society and ultimately producing social force and value. Cultivating art major professional talents need to combine social practice and the process of social progress, and the cultivation content also need to down to earth and conform to the time.

Pay Attention to the Researches of Art Instructors about Industry University Research Institution Drive. The drive of industry university research institution in art education system is fully considering the needs of market and business. That is to say, art curriculum is the necessary course system to be set up in college at present. And in the specific practice process, college has worked out a set of teaching mode of art talents training and production and industry university research institution integration integrated construction. Successful teaching tips need to be practiced from three aspects: adjusting teaching contents, teaching concept and teaching mode. Art colleges focus on learning is aimed at knowing market, basic situation of enterprise, future development trend of enterprise and set an education objectives and talents training system which is suitable for business and society. Only focus on the need of enterprises and individualized to make teaching more practical will the colleges have more specific and social practical art curriculum be. Only make the talents training mode of art colleges possess the art professional skills requirements market survey and master the real need and driving force of enterprises, can the college adopt more effective and practical public art curriculum teaching outline and teaching objectives in allusion to teaching content and method and actively promote the practical teaching of teamwork. In order to achieve both practical and comprehensive literacy teaching objectives, the existing teaching content must be adjusted. The teaching content of courses should take the demand of enterprises as the 
starting point and integrate all the teaching resources which can be grasped so as to enrich the teaching content and transform the inherent, dogmatic teaching idea.

Pay Attention to the Consistency of Content and Objectives of Industry University Research Institution. It is the eternal theme of higher art education to improve the overall quality of talents training, the employment rate of talents and the comprehensive content of talents training from training objective and content of art curriculum. Of course, it is also a very difficult problem. In order to improve the quality, colleges need to mobilize educational resources, emphasis on the consistency of industry university research institution education targets and education content and combine the quality standard dynamic and diversified system. When establishing of talents specifications, talents content, talents type, talents needs, talents personality diversity of professional talents, colleges should do a good job of accurate positioning, establish multi-perspective of quality and identify the orientation of college art major. Establish a local and applied college orientation and mission of running college according to the quality of art talents training standards. Pay attention to industry university research institution interactive in the training process of art college profession or pure art profession. The inevitable choice of higher education and different types of education will get the answer in continuous competition. A very effective way in art profession is to determine the regional economic development of the needs of the community and the actual situation of the school, and increase the effective function of talents training mode and method. For the deficiencies in teaching content, resources and talents training guarantee strength, college can use some methods to solve the misfit problems between college, social students and employing units. Improve misfit extent of professional training and curriculum system for industry university research institution interactive. Earnestly put heads together to solve the problems in the education process.

\section{Intersecting Transverse Education and Longitudinal Education of Industry University Research Institution}

Industry university research institution teaching mode is intersecting transverse education and longitudinal education teaching mode. It is a system using of the teaching mode and a kind of effect from the combination of teaching mode and teaching objectives. From the perspective of transverse education, industry university research institution is a practical result of college educational model adapted to the need of educational system and social development. From the perspective of longitudinal education, industry university research institution is the educational method to achieve sustainable development of social education system and to create mechanism and promote the close combination of industry university research institution.

That is to say, education is a matter of generation and changeless. It is not a training plan in the short term but long-term steadily college brand building. It is a teaching method that can promote the entire education system and the continuous development of educational content. Therefore, adhere to the teaching methods and education system of industry university research institution actually is to insist the reform and innovation of the use of personnel training model of reform and innovation. Promote research experiments, synthesis and design, basic research methods, personnel training mode and other aspects of different levels of talent training echelon combination. It is a kind of improvement on educational mode of government taking the lead in encouraging college as the actual performer.

Practical Skills and Practice of College Art Major. For the need of art design major development feature, companies want faster practice results when recruiting talents. Students often need to quickly apply their professional skills into social practice after entering society. Therefore, the traditional teaching mode and methods have been able to meet the current demand of enterprises for practical skills and experience. And the problem of students' poor operating capability in many art institutions has drawn a lot of attention. Therefore, the running mode of combining college with enterprise is a good education practice method for practice and training base to get a guarantee. In other words, the current teaching methods of many art colleges adopt to combine the internal and external educational base with the college scientific research teams. Using a way to increase the 
actual way to cultivate students' social practice ability and enhance the social practice of students. And in this process, many institutions also take a double certificate of talents training mode.

The Teaching and Scientific Research Strength of College art Major. Of course, the word research refers to scientific research strength in education process. Scientific research is the basis of scientific practice and artistic practice. If there is no teaching and scientific research strength in college art major, then the students would have no practice basis, theoretical guidance and teachers would loss the teaching backbone. Therefore, in the process of industry university research institution, the teaching and scientific research strength should not be denied. The college should further develop the professional from technical point of view of teaching and research mode and method. The current theoretical basis of strengthening the connotation construction of talents training and reforming mode are: cultivating high-skilled professional art talents, strengthening teaching and research ability of art colleges and improving the level and quality of teaching and research of the whole art institutions.

The Practice Teaching Diversification of Art and Design Program. Therefore, an effective teaching mode which many art colleges adapting in the talents training model reform is: using quick teaching method of college-enterprise cooperation and college-research cooperation, using art educational plan of industry university research consistent talents training mode, and achieve the teaching practice process diversification in the comprehensive plan and year plan of artistic development. The diversification of college learning content can not only make the students experience short-term teaching practice but also can make the enterprises sign art contract agreement with students directly through the bond between college and enterprise. Make graduation subsidies, design and other practical aspects as effective supplement. To promote the general proficiency of modern art college talents training with flexible and diverse talents training mode and teaching practice. Enterprises can also prepare professional lectures regularly in the college. It would play a very good role for improving the teaching literacy and methods of the college students and teachers. To carry out innovative talent training strategy based on industry university research, colleges need to make changes according to their original basis and break the existing talents training mode. They should put more energy focus on the actual requirements of enterprises and adapt the talents training strategies of "gearing production to demand, deciding configuration to demand" to cultivate students. The ultimate goal of cultivating talents in colleges is to enable graduates to devote themselves to society and enterprises in the future.

The Team Spirit of "Design Team" Facing Competition. Actively promote the cooperative teaching methods, divide art into several groups and arrange more teamwork assignments to complement each other's advantage, learn from each other and promote each other. The main reason for promoting teamwork practice teaching is enterprise demand. Enterprises attach great importance to teamwork in the future actual production process. Many art students have a high artistic talent, but their performance is not that good on work. The main reason is that they less of team consciousness. This makes it difficult for them to integrate into the corporate team, and can't play their own talent. Therefore, in the learning stage we need to attach importance to student teamwork and team awareness ability training. Only with the team's sense of cooperation, it would be beneficial to the future of art students' career success in the career.

\section{Conclusion}

Nowadays, art education is no longer in the time to be highbrow. Art education must meet the needs of itself, teaching and research and the general trend art enterprises and social development. Only take advantage of the times can art colleges achieve the new breakthrough of industry university research institution interactive talents training mode research.

\section{Acknowledgements}

Project Name: Production, Study, Research and Use, Personnel Training Mode of Synergy between Universities and Factories---Take the Course of "Ceramic Molding" for Example. 
Project Number:JG2015B035."Special Project of xi 'an University's Teaching Research and Reformation"

\section{References}

[1] X.F. Liu: Knowledge Economy, (2017) No. 5, p 136-137

[2] Y. Chen, B. Jiang and Q.Z. Gu: Journal of Jiangxi Science and Technology Normal University, (2016) No. 2, p 118-123

[3 J.G. Gao, N. Guo, W.M. Guo, C.M. Li, X.H. Chi, H.T. Hu and X.H. Zhang: Innovation and Entrepreneurship Education, (2016) No. 1, p 71-73

[4] D.L. Sun and Q. Wen: Popular Literature and Art, (2015) No. 22, p 251-252

[5] S.Q. Jiang and X.Y. Gong: Journal of Hubei Institute of Engineering, (2015) No. 5, p 80-84

[6] S.G. Tan: Popular literature and art, (2015) No. 10, p 200-201

[7] X.P. Zhou: College Education, (2015), No 1, p 78-79

[8] H.X. Li: Education and Occupation, (2014), No 35, p 136-137

[9] X.X. Guo: Art Review, (2014) No 12, p 119-121

[10] Y. Pan: Art Education Research, (2014) No 9, p 136-137

[11] X.M. Ren, Z.F. Jia, Z.F. Wang, M.K. Zong and X.F. Wang: Journal of Harbin University, (2013) No 8, p 127-129

[12] J. Liu: Journal of Hotan Teachers College, (2009) No 1, p 35-36 